\title{
ON THE FORMATION OF LACTOSE
}

By FRAnCis H. A. MARShall, M.A. (Cantab.), D.Sc. (Edin.), Carnegie Fellow and Lecturer on the Physiology of Reproduction in the University of Edinburgh, AND J. M. KIRKNESS, M.D. (EDIN.), F.R.C.S.E.

From the Physiological Department, University of Edinburgh. (Received October 16th, 1906)

The following note contains an account of certain experiments which were undertaken to test Paul Bert's hypothesis regarding the formation of lactose from glucose.

Bert's first experiment was upon a guinea-pig, in whose mammary glands he searched for an intermediate substance out of which it would be possible to form lactose in an appreciable quantity, but he failed to discover any such substance. He next proceeded to remove the mammary glands from two goats which were subsequently allowed to become pregnant, and he tested the urine of these animals to see if he could find a reducing substance both during the period of pregnancy and for a short time after parturition. No such agent could be found in the urine of either of the goats during pregnancy, but in one of them for about nine days after the birth of the kid a substance which markedly reduced cupric sulphate was discovered in considerable quantity, while in the case of the other goat the effect produced was similar though less pronounced. Bert concluded that the reducing substance was glucose, but it does not appear that he employed any further test to differentiate it from other reducing agents. He supposed further that the glucose in the urine represented glucose which in normal animals would have been converted into lactose in the mammary glands.

Bert's experiments were repeated by Moore and Parker, who first examined normal goat's urine, and found that it gave a feeble reduction with Fehling's and Almen's tests, but not sufficient to indicate the presence of an appreciable quantity of sugar. The mammary glands of two pregnant goats were subsequently removed. Parturition occurred in due course. In the one case no change 
whatever could be detected in the urine after parturition, and in the other only a very slight increase in the reducing power of the urine was discernible for two days, disappearing on the third day. No result was obtained with the phenylhydrazine test, and in the opinion of the investigators 'no reducing sugar was present, but only traces of a substance with feeble reducing power.' These results, therefore, were opposed to those of Bert, and the authors conclude that the complete process of lactose formation takes place in the cells of the mammary glands.

The question of lactose formation has been recently reopened by Porcher, who does not appear to have been aware of the experiments of Moore and Parker. Like the latter, Porcher also operated on a goat, repeating Bert's experiment. After parturition, which is said to have taken place normally, an ' intense glycosuria' occurred. The phenylhydrazine test showed that the sugar was glucose, and not lactose or maltose. Porcher also removed the mammary glands from four goats and one cow during lactation, and for a few hours after the operation obtained marked glycosuria. As a result of these experiments he concludes that the truth of Bert's theory is established. ' Il parait donc irréfutablement démontré que la mamelle est l'organe producteur du lactose et que, pour l'élaboration de ce dernier sucre, elle en emprunte les matériaux au glucose que lui apporte le sang.' 'Il n'est pas niable que l'activité de la glande hépatique doive être plus grande pendant la lactation, puisque cet organe, dont un des rôles est de déverser le sucre dans le sang, devra en outre faire face, en vue de la sécrétion lactée, à la mise en liberté du glucose qui sera ultérieurement transformé en lactose.' (Porcher, 1906.)

For the purpose of our own experiments we made use of guineapigs, which differ from most other rodents in having only two mammary glands and teats situated one on each side of the abdomen. We removed the mammary glands from ten animals, only one of which was pregnant at the time of the operation. In some instances a single transverse incision from teat to teat was made across the skin of the abdomen, and each gland was dissected away from the skin and underlying tissue; in other cases two cuts were made, 
one on each side, an uninterrupted bridge of skin being left between the two incisions while the mammary tissue was removed as in the former cases. The teats were also removed along with a small piece of skin. The edges of the cut skin were afterwards sewn together, and the wounds allowed to heal, a process which usually occurred very rapidly. Three of the guinea-pigs unfortunately died either from disease or accident some time after the wounds had completely healed. In each of these animals no trace of mammary tissue could be found post mortem. Considerable difficulty was experienced in inducing the guinea-pigs to breed after the removal of the glands, some of them failing to do so although kept for over eight months in company with males, and in an apparently perfectly healthy condition. Four guinea-pigs, however, eventually became pregnant. The following is an account of these four experiments :-

Experiment I.-The mammary glands were removed from a large rough-haired guinea-pig in the beginning of December. At the end of February the animal seemed to be pregnant. ${ }^{1}$ The urine was tested and no sugar or albumen was found to be present. On April 7 th one young one was born prematurely and found dead. On April 8th the urine collected during the previous night was tested with Fehling's solution, which turned a greenish-yellow colour on boiling for three minutes. No sugar could be detected with the phenylhydrazine test. On April 9th Fehling's solution gave no reduction whatever. This guinea-pig was again put beside a male and on July 30 th was a second time observed to be palpably pregnant. Parturition did not occur until August 24th, when three young ones were born apparently at full time. The urine was tested for several days subsequently when no trace of sugar could be detected either by Fehling's test or by the phenylhydrazine test. The three young ones all survived, feeding for themselves in spite of the fact that the mother was unable to suckle them.

Experiment II.-The glands were removed from a small rough guinea-pig early in December. At the beginning of February it was observed to be pregnant. On February 2Ist the guinea-pig appeared to have aborted while in company with another guinea-pig but no fotus could be found, having probably been eaten. The urine was then examined and found by Fehling's and the phenylhydrazine tests to contain glucose in perceptible quantities. A small amount of albumen was also found to be present. The animal appeared to be ill and on February 28th died. The post mortem showed that the animal had died from the effects of tubercle on the liver and intestinal lymphatic glands. Signs of recent abortion were also noted. It is evident that this experiment was quite inconclusive.

I. The period of gestation in the guinea-pig is from sixty-three to sixty-six days. 
Experiment III.-The mammary glands were removed from a smooth-haired guineapig early in March. On July Ioth it had three young. The animal was immediately placed in the metabolism cage and the urine of twenty-four hours collected. The urine was then tested by Fehling's and Nylander's solutions. No trace of sugar could be detected. Also Dr. W. Cramer kindly tested with the polarimeter and found no indication of sugar. On July I2th (i.e., next day) the urine was again tested with Fehling's solution which again gave no reduction. The same result was obtained next day.

Experiment $I V$.-The mammary glands were removed from a guinea-pig in an advanced stage of pregnancy on June 16th. Four young ones were born on June 20th. The urine was collected for the next twenty-four hours and examined on June 2 Ist. Fehling's solution gave a yellowish green precipitate on prolonged boiling, but the phenylhydrazine test was negative. No albumen was present. The same result was obtained next day and for several days subsequently on which the urine was tested. Thus no trace of sugar could be discovered. Both wounds were healed by June 23 rd.

(N.B.-This was the only experiment in which the wounds were not completely healed at the time of parturition).

Leaving out of account Experiment 2, in which the animal was suffering from tubercle and had recently aborted, the experiments indicate that removal of the mammary glands does not bring about a condition of glycosuria after a subsequent parturition, and that at such a time there is normally no increase of glucose in the blood such as one would suppose if Bert's hypothesis were true.

The possibility suggested itself (although it appeared to be exceedingly unlikely) that guinea-pig's milk might be deficient in sugar as compared with goat's milk, since guinea-pigs when newly born are not dependent upon the mother suckling them to nearly the same extent as most mammals, and consequently the milk might be somewhat abnormal. Accordingly we obtained a few drops of guinea-pig's milk by expressing it from the teats, and after diluting it with a little water tested it with Fehling's solution, which gave a very marked reduction. It was not possible to obtain sufficient milk to estimate the amount of sugar, but it was evident that the sugar was present in considerable quantity.

It is known that lactosuria occurs occasionally in women during lactation, and also, according to some, in the later stages of pregnancy (Hofmeister, 1878; Porcher, 1906); and it is usually supposed that the lactose got rid of in this way is derived from the charged mammary 
glands, being absorbed into the blood and afterwards excreted by the kidneys. It occurred to us, therefore, that the unidentified sugar found by Bert after parturition in the goat's urine might be lactose which had been found in a small portion of mammary gland that had been left behind accidentally at the time of the operation, and had subsequently undergone hypertrophy. ${ }^{1}$ Under such circumstances the milk (if formed) with its contained lactose would have no way of escape, and its constituent parts might become re-absorbed into the blood. However this might be, on isolating a suckling guinea-pig which had recently given birth to young, and on examining its urine, sugar was found to be present in considerable quantity, but the crystals formed on applying the phenylhydrazine test showed that the sugar was for the most part glucose, while lactose, if present at all, was only there in very small amount. On the following day the guinea-pig's urine had become normal, no reduction being given by Fehling's test. On repeating the experiment with a suckling rat shortly after parturition a negative result was obtained, the rat's urine having no reducing action on Fehling's solution.

These experiments show that glycosuria may take place after parturition in normal unoperated animals, but that it does not do so invariably. When glycosuria does so occur, its occurrence is probably comparable to post-operative glycosuria, the cause of which is not understood.

The glycosuria observed by Porcher after removal of the mammary glands during lactation may probably be explained as a post-operative effect, and cannot be cited in support of Bert's hypothesis.

Evidence has been adduced by various authors that the growth of the mammary glands and the formation of milk are the direct or indirect result of a specific stimulus arising in the placenta (Keiffer, 1902; Halban, 1905) or in the foetus (Lane-Claypon and Starling, 1906). In view of the facts cited above it is evident that this stimulus

1. Ribbert (1894) has shown that if in performing the operation of removal of the mammary glands the operator fails to extirpate all the tissue completely an active regenerative process rapidly takes place from the tissue that is left behind. 
must act solely on the tissue of the mammary glands, and not upon the liver or some other organ in the body in addition, as one would have to suppose were Bert's hypothesis proved to be correct.

Further, the specific mammary hormone is apparently quite inactive in the complete absence of the mammary glands, and in such cases is ineffective in causing a new formation of gland tissue, for on killing the guinea-pig (referred to in Experiment I) which had become twice pregnant after the extirpation of the glands, not a trace of mammary tissue could be discovered.

\section{Postscript}

Since concluding this paper the guinea-pig referred to in Experiment III became pregnant a second time and had young ones in the middle of November. The young ones were evidently born at full time. The urine of the mother was again tested (for a day after parturition), when no sugar could be detected. Albumen was present in small quantity.

We may note also that Shattock (1905) removed the mammary glands of a guinea-pig which afterwards became pregnant and had young at full time. Shattock carried out his experiment to test the view that the mammary glands elaborate an internal secretion necessary for the growth of the foetus. It will be seen that our experiments confirm Shattock's conclusion that there is no such secretion formed.

\section{REFERENCES}

Bert, C. R. de l'Acad. des Sciences, Vol. LXXXVIII, 1884 .

Halban, Arcb. f. Gynäk, Vol. LXXII, 1905.

Hofmeister, Zeitsch. f. Pbysiol. Cbem., Vol. I, 1878.

Keiffer, Bull. de la Societé Belge de Gyn. et d'Obstet., 1901-02.

Keiffer, Soc. Obstet. de France, 1902.

Lane-Claypon, and Starling, Proc. Roy. Soc., B, Vol. LXXVII, 1905.

Moore and Parker, Amer. Four. of Phys., Vol. IV, 1900.

Porcher, C. R. de l'Acad. des Sciences, Vol. CXXXVIII, 1904.

Porcher, Ibid., Vol. CXL, 1905.

Porcher, Ibid., Vol. CXLI, I905.

Porcher, ' De la Lactosurie.' Monograpbies Cliniques, Paris, 1906.

Ribbert, Arch. f. Entwicklungs-mechanik, Vol. I, 1894.

Shattock, Proc. Patb. Soc., Lancet, Part II, 1905. 